\title{
Classic detective puts his finger on the clue
}

\section{A fictional gumshoe was first to pick up the intriguing criminal potential of 'gummy fingers'.}

Sir - Your News report on the fake fingerprints made by mathematician Tsutomu Matsumoto, using gelatin and a plastic mould (Nature 417, 676; 2002), is interesting, but hardly novel. An analogous but more elegant technique was described by the great British mystery writer R. Austin Freeman in The Red Thumb Mark, first published by Collingwood Brothers, London, in 1907.

In the book, Freeman, in the guise of his scientific detective Dr Thorndyke, explained how regions of a plate of "chromicized gelatine" exposed to light under a negative image of a fingerprint would be inversely soluble in hot water, according to how much light each area received. Gelatin under the fingerprint ridges would receive more light and would be preserved when the plate was rinsed with hot water. A three-dimensional gelatin replica of a fingerprint would result.

"The process that I have described," said Thorndyke, "is, in all essentials, that which is used in the reproduction of penand-ink drawings, and any of the hundreds of workmen who are employed in that industry could make a relief block of a finger-print with which an undetectable forgery could be executed." I have no doubt that Freeman's gelatin fingerprint could fool an optical scanner as well as Matsumoto's.

Many more details are provided in The Red Thumb Mark, which mystery buffs among Nature's readers will doubtless enjoy - even though I have given away part of the ending. This is one of several Dr Thorndyke stories that have recently been reprinted (Stratus, London, 2001).

David Ehrenfeld

Department of Ecology, Evolution, and Natural Resources, Cook College, Rutgers, the State University of New Jersey, 14 College Farm Road, New Brunswick, New Jersey 08901-8551, USA

\section{Microcredit tackles both poverty and birthrate}

Sir - It is worrying that population growth should be absent from the agenda of the forthcoming United Nations World Summit on Sustainable Development, as outlined by Wolfgang Lutz et al. in Correspondence (Nature 418, 17; 2002).

It is also worrying that empowerment of women can be mentioned without pointing to successful enterprises such as the Grameen Bank of Bangladesh, which makes small loans to help penniless women set up in business. These are known as 'microcredit' or 'microlending' enterprises. To read some of the numerous success stories arising from these small loans, often $\$ 100$ or less, see, for example, www. greenstar.org/microcredit or read Banker to the Poor, the autobiography of Grameen Bank founder Muhammad Yunus (with Alan Jolis; Aurum, London, 1998).

Microlending, under the rules pioneered by the Grameen Bank, has turned the empowerment of women and the reduction of fertility from mere slogans into a growing reality.

Michael E. McIntyre

Centre for Atmospheric Science, Department of Applied Mathematics and Theoretical Physics, Cambridge University, Silver Street, Cambridge CB3 9EW, UK

\section{Israeli terms are used for consistency, not politics}

Sir - Knut Rognes in Correspondence (Nature 417, 379; 2002) accused the Israel Journal of Entomology (IJE) of being political, not scientific, claiming that the editor (I. Y.) and a member of the editorial board (A.F.) refused to accept the geographical terms he used for Israel and adjacent areas in a manuscript he intended to submit (see also Nature 418,$273 ; 2002$ ).

The policy of the IJE has always been to promote science, not politics. One aspect of good science is a precise and consistent terminology. It is particularly difficult to maintain consistent geographical terminology in an area such as that covered by our journal, because of the prevalent and concurrent use of several languages (such as Arabic, Hebrew and English) for the names of the same localities, and the existence of many spelling variants. To overcome this difficulty, the IJE established a standard specified in the Notes for Authors (latest version July 2001), as follows: "Names of localities in Israel will be given as they are transliterated in the Israel Touring Map" and "Regions in Israel and nearby areas should follow the Fauna Palaestina map". These two maps are given for convenience of scientific purposes only, without any political connotation.

Not only has Rognes tried to impose on us his irrelevant political views, but these views are literally wrong. At present, there is no Palestinian state. If and when a Palestinian state is established, with defined boundaries and scholarly official maps, we will use their transliterated spelling for the appropriate localities. Until then, we will remain with our current policy, as would any scientific journal (including the journal Fauna of Saudi Arabia, which, as correctly mentioned by Rognes, ignores the existence of recognized states).

The IJE has never "banned any mention of Palestinian national territory", as Rognes claims; as a scientific journal we simply do not find it necessary to deal with political concerns of authors. We hope that, following this clarification, Rognes will return to us, and we shall welcome his paper in the IJE, where it indeed belongs. Amnon Freidberg ${ }^{\star}$, Ilan Yarom $\dagger$

${ }^{*}$ Department of Zoology, Tel Aviv University, Tel Aviv 69978, Israel

$\dagger$ Hazeva R\&D Center, Ben-Gurion University of the Negev, PO Box 653, Beer Sheva 84105, Israel

\section{Bioethics: centres reveal sponsors but not policy}

Sir - I would like to correct a statement attributed to me in the News story "Code of conduct for bioethics branded 'soft' on corporate ties" (Nature 417, 885-886; 2002). Your article states that the University of Pennsylvania's centre is the only one to provide information about its funding sources on its website.

On 7 June, the Center for Science in the Public Interest wrote to more than 125 bioethics centres and journals, urging them to develop or strengthen their conflict of interest policies. Our survey indicates that although only one centre the University of Pennsylvania's Center for Bioethics - provides its policy on external funding and conflicts of interest on its website, several others do publicly disclose information about their funding sources.

Although we believe that bioethics centres, individual bioethicists and journals are doing an extremely poor job of disclosing potentially biasing financial ties, they are not quite as negligent as your article suggests. Virginia Ashby Sharpe Center for Science in the Public Interest, 1875 Connecticut Avenue, NW, Suite 300, Washington, DC 20009-5728, USA www.integrityinscience.org 